\title{
IMPLIKASI MATERI BAHASA INDONESIA DALAM BUKU TEMATIK TERHADAP PERKEMBANGAN PENGETAHUAN SISWA SD/MI KELAS IV
}

\author{
Syahru Ramadhan \\ Institut Agama Islam (IAI) Muhammadiyah Bima \\ Email: syahrupgmi05@gmail.com
}

\begin{abstract}
Abstrak
Penerapan Kurikulum 2013 sangat berdampak secara signifikan pada proses pembelajar yang terdapat pada tiap-tiap sekolah khususnya pada tingkat SD/MI. Hal ini mengharuskan pihakpihak yang terkait secara langsung dalam proses pembelajaran dalam ini adalah guru untuk memahami orientasi pada kurikulum 2013, sehingga dapat diaktualisasikan dengan baik dan benar sesuai dengan tujuannya. Dalam pembelajaran buku tematik kelas IV SD/MI terdapat beberapa disiplin ilmu pengetahuan yakni, Pendidikan Agama Islam, Matematika, Bahasa Indonesia, IPA, IPS, SBDB, PJOK. Agar siswa lebih memahami tentang materimateri yang diajarkan oleh guru diatas, maka seorang pendidik (guru) pada proses pembelajaran dalam buku tematik harus melibatkan siswa secara langsung dengan materi-materi dan lingkungan sekitarnya secara kontekstual, supaya siswa lebih aktif dan kreatif. Adapun materi bahasa indonesia dalam buku tematik SD/MI kelas IV tidak dibahas secara lugas dan jelas seperti yang terdapat dalam buku ajar KTSP, sehingga berdampak pada perkembangan pengetahuan siswa yakni siswa tidak memiliki pengetahuan tentang penulisan huruf besar dan huruf kecil, kalimat baku dan kalimat tidak baku, menulis ide pokok dalam paragraf, tanda petik, cara membaca simbol atau lambang. Untuk mengatasi hal tersebut, maka pihak sekolah mewajibkan siswa untuk mengikuti proses pembelajaran tambahan atau les, supaya siswa memperoleh pengetahuan serta pemahaman tentang materi-materi bahasa indonesia yang tidak ada dalam buku tematik.
\end{abstract}

Kata Kunci: Bahasa Indonesia, Tematik, Pengetahuan Siswa

\section{PENDAHULUAN}

$\mathrm{I}$

mplementasi kurikulum 2013 di Sekolah/Madrasah yang sudah dimulai di sejumlah sekolah dari sekolah dasar sampai sekolah menengah atas, secara terbatas, merupakan salah

satu bentuk inovasi pendidikan yang dilakukan pemerintah. Dalam pandangan Ridwan Abdullah Sani, pengembangan kurikulum 2013 ini merupakan upaya peningkatan mutu pendidikan untuk menghasilkan lulusan yang kreatif dan mampu menghadapi kehidupan dimasa yang akan dating (Ridwan Abdullah Sani, 2014). Hal serupa juga 
diungkapkan Abdul Majid, pengembangan kurikulum 2013 adalah bagian dari strategi meningkatkan capaian pendidikan. Disamping kurikulum, sesungguhnya ada sejumlah faktor lain yang punya peran penting diantaranya lama siswa bersekolah; lama siswa tinggal di sekolah; pembelajaran siswa aktif berbasis kompetensi; buku pegangan dan peranan guru sebagai ujung tombak pelaksanaan pendidikan (Abdul Majid, 2014).

Implikasi diterbitkannya Peraturan Pemerintah Nomor 32 tentang Perubahan atas Peraturan Pemerintah nomor 19 tahun 2005 tentang Standar Nasional Pendidikan ialah perubahan model pendekatan pembelajaran yang dilakukan di Sekolah Dasar. Pendekatan pembelajaran tersebut adalah pendekatan pembelajaran tematik terpadu atau yang seringkali disebut sebagai tematik integratif. Pembelajaran tematik terpadu merupakan pendekatan pembelajaran yang mengintegrasikan berbagai kompetensi dari berbagai mata pelajaran dalam berbagai tema. Pendekatan pembelajaran ini digunakan untuk seluruh kelas pada sekolah dasar. Pembelajaran dengan pendekatan tematik ini mencakup seluruh kompetensi mata pelajaran yaitu: PPKn, Bahasa Indonesia, IPA, IPS, Matematika, Pendidikan Jasmani Olahraga dan Kesehatan, Seni Budaya dan Prakarya kecuali mata pelajaran Pendidikan Agama dan Budi Pekerti. Kompetensi mata pelajaran IPA pada kelas I - III diintegrasikan pada mata pelajaran Bahasa Indonesia dan Matematika, sedangkan untuk mata pelajaran IPS diintegrasikan ke mata pelajaran Bahasa Indonesia, PPKN dan Matematika. Kompetensi dasar IPA dan IPS di kelas IV-VI masing-masing berdiri sendiri.

Pendekatan ini dimaksudkan agar peserta didik tidak belajar secara parsial sehingga pembelajaran dapat memberikan makna yang utuh pada peserta didik seperti yang tercermin pada berbagai tema yang tersedia. Tematik terpadu disusun berdasarkan berbagai proses integrasi yaitu integrasi intra-disipliner, inter-disipliner, multi-disipliner dan transdisipliner.

Pembelajaran tematik merupakan pembelajaran bermakna bagi siswa. Pembelajaran tematik lebih menekankan pada penerapan konsep belajar sambil melakukan sesuatu. Oleh karena itu, guru harus 
merancang pengalaman belajar yang mempengaruhi kebermaknaan belajar siswa. Pengalaman belajar menunjukan kaitan unsur-unsur konseptual yang menjadikan proses pembelajaran lebih efektif. Dikatakan bermakna karena dalam pembelajaran tematik, peserta didik akan memahami konsep-konsep yang mereka pelajari melalui pengalaman langsung dan menghubungkannya dengan konsep lain yang telah dipahaminya. Pembelajaran tematik menekankan pada keterlibatan peserta didik secara aktif dalam proses pembelajaran, sehingga peserta didik dapat memperoleh pengalaman.

Proses belajar tidak sekedar menghafal konsep-konsep atau fakta belaka, tetapi kegiatan menghubungkan konsep-konsep untuk menghasilkan pemahaman yang lebih utuh. Hal ini sejalan dengan falsafah konstruktivisme yang menyatakan bahwa manusia mengkonstruksi pengetahuannya melalui interaksi dengan obyek, fenomena, pengalaman, dan lingkungannya. Pengetahuan tidak dapat ditransfer begitu saja dari seorang guru kepada anak, Tetapi peserta didik perlu dilibat secara langsung dengan materi-materi yang diajarkan.

Pembelajaran materi bahasa Indonesia diarahkan untuk meningkatkan kemampuan peserta didik untuk berkomunikasi dalam bahasa Indonesia dengan baik dan benar, baik secara lisan maupun tulis, sekaligus mengembangkan kemampuan berpikir kritis dan kreatif. Peserta didik dimungkinkan untuk memperoleh kemampuan berbahasanya dari bertanya, menjawab, menyanggah, beradu argumen dengan orang lain. Sehingga dalam rangka memperoleh kemampuan tersebut, maka pendidik dalam hal ini memberikan pengajaran materi bahasa indonesia yang dalam pembelajaran buku tematik ternintegrasi pada mata pelajaran lain dengan metode dan serta strategi pembelajaran yang baik dan tepat.

\section{METODOLOGI PENELITIAN}

Jenis penelitian yang digunakan dalam penulisan ini adalah penelitan kepustakaan (Library Research), yaitu serangkaian penelitian yang berkenaan dengan metode pengumpulan data pustaka, atau penelitian yang digali melalui beragam informasi kepustakaan seperti 
buku, ensiklopedi, jurnal ilmiah, koran, majalah, penelitian terdahulu dan dokumen (Nana Syaodih, 2009). Penelusuran pustaka ini dibatasi pada pembahasan tertentu dalam rangka untuk memperoleh data penelitian. fokus riset pustaka ini yaitu pada pengkajian dan analisis terhadap berbagai literatur yang memiliki hubungan dengan tema penelitian dan diakhiri dengan penarikan kesimpulan sebagai hasil temuan dalam penelitian.

\section{PEMBAHASAN}

\section{Muatan Materi Bahasa Indonesia Dalam Buku Tematik Kelas} IV

Prototipe buku ajar bahasa Indonesia tematik kelas IV terdiri dari sembilan Tema, Yaitu : (a) Indahnya kebersamaan; (b) Selalu berhemat energi; (c) Peduli terhadap makhluk hidup; (d) Berbagai pekerjaan; (e) Menghargai jasa pahlawan; (f) Indahnya negeriku; (f) Cita-cita ku; (g) Daerah tempat tinggal ku; (h) Makanan sehat dan bergizi.

Prototipe buku ajar tematik pada kelas IV dipenuhi ilustrasi yang menarik, berwarna-warni, dan disesuaikan dengan siswa SD kelas IV. Adapun gambaran prototipe buku ajar bahasa indonesia tematik SD kelas IV dengan muatan materi bahasa indonesia sebagai berikut (Kemendikbud, 2014) :

Judul tema 1 adalah indahnya kebersamaan. Siswa kelas IV belajar memahami bahwa manusia hidup selalu tidak bisa lepas dari manusia yang lain serta mengolah informasi dari teks dengan lisan dan tulisan, sehingga harus bersosialisasi, siswa juga belajar bagaimana caranya berbagai dan mengerjarkan tugas bersama serta mengolah informasi dari teks dengan lisan dan tulisan.

Judul tema 2 adalah selalu berhemat energi. Pada tema ini siswa kelas IV belajar memahami bahwa energi sangat penting dalam kehidupan manusia, siswa juga belajar bagaimana caranya berbagi dan mengerjakan tugas bersama serta mengolah informasi dari teks dengan lisan dan tulisan. 
Judul tema 3 adalah peduli terhadap makhluk hidup. Siswa kelas IV belajar tentang memahami bentuk-bentuk sikap melestarikan alam serta mengenal dan memahami cara menjaga peninggalan budaya, misalnya candi serta mengolah informasi dari teks dengan lisan dan tulisan.

Judul tema 4 adalah berbagai pekerjaan. Siswa kelas IV belajar tentang menemukan informasi yang berkaitan dengan berbagai jenis pekerjaan melalui kegiatan membaca serta menyajikan cerita singkat misalnya tentang proses pembuatan teh setelah kegiatan membaca dilakukan.

Judul tema 5 adalah menghargai jasa pahlawan. Pada tema ini siswa kelas IV belajar tentang menemukan informasi yang terkait dengan kehidupan para pahlawan pada masa dulu serta membuat ulasan sederhana dengan mengaitkan dengan kehidupan masa sekarang setelah proses membaca dilakukan.

Judul tema 6 adalah indahnya negeriku. Pada tema ini siswa kelas IV belajar tentang menggali informasi dari teks cerita tentang lingkungan dan sumber daya alam agar memiliki rasa kepedulian terhadap lingkungan dan sumberdaya alam yang ada di sekitarnya.

Judul tema 7 adalah Cita-citaku. Pada tema ini siswa kelas IV belajar tentang menggali informasi dari teks wawancara tentang jenis-jenis usaha, pekerjaan dan kegiatan ekonomi kemudian menceritakan hasil wawancaranya.

Judul tema 8 adalah Daerah tempat tinggal ku. Pada tema ini siswa kelas IV belajar tentang menggali informasi dari teks laporan hasil pengamatan tentang gaya, gerak, energi, panas, bunyi dan cahaya dengan lisan maupun tulisan.

Judul tema 9 adalah makanan sehat dan bergizi. Pada tema ini siswa kelas IV belajar tentang bagaiman membuat peta pikiran dari teks cerita pertualangan, menceritakan suatu peristiwa saat mengkonsumsi makanan.

Dari 9 tema pembelajaran yang ada dalam buku tematik SD/MI kelas IV serta muatan-muatan materi yang sudah dijelaskan diatas dapat disimpulkan bahwa materi bahasa indonesia tidak 
muncul secara eksplisit, tetapi terintegrasi pada materi-materi lain sehingga lebih dituntun kepada siswa agar lebih aktif, kreatif serta inovativ.

Berdasarkan Standar Kompetensi SD/MI, berikut Kompetensi yang harus dikuasai siswa kelas IV SD/MI pada mata pelajaran Bahasa Indonesia, sebagai berikut (Kemendikbud, 2014):

\begin{tabular}{|c|c|}
\hline KOMPETENSI INTI & KOMPETENSI DASAR \\
\hline $\begin{array}{l}\text { 1. Menerima, menjalankan, dan } \\
\text { menghargai ajaran agama yang } \\
\text { dianutnya }\end{array}$ & $\begin{array}{l}\text { 1.1 Meresapi makna anugerah } \\
\text { Tuhan Yang Maha Esa berupa } \\
\text { bahasa Indonesia yang diakui } \\
\text { sebagai bahasa persatuan yang } \\
\text { kokoh dan sarana belajar untuk } \\
\text { memperoleh ilmu pengetahuan } \\
\text { 1.2 Mengakui dan mensyukuri } \\
\text { anugerah Tuhan yang Maha Esa } \\
\text { atas keberadaan lingkungan dan } \\
\text { sumber daya alam, alat teknologi } \\
\text { modern dan tradisional, } \\
\text { perkembangan teknologi, energi, } \\
\text { serta permasalahan sosial }\end{array}$ \\
\hline $\begin{array}{l}\text { 2. Menunjukkan perilaku jujur, disiplin, } \\
\text { tanggung jawab, santun, peduli, dan } \\
\text { percaya diri dalam berinteraksi dengan } \\
\text { keluarga, teman, guru, dan tetangganya }\end{array}$ & $\begin{array}{l}2.1 \text { Memiliki kepedulian } \\
\text { terhadap gaya, gerak, energi } \\
\text { panas, bunyi, cahaya, dan energi } \\
\text { alternatif melalui pemanfaatan } \\
\text { bahasa Indonesia } \\
2.2 \text { Memiliki kedisiplinan dan } \\
\text { tanggung jawab terhadap } \\
\text { penggunaan alat teknologi } \\
\text { modern dan tradisional, proses } \\
\text { pembuatannya melalui } \\
\text { pemanfaatan bahasa Indonesia } \\
2.3 \text { Memiliki perilaku santun dan } \\
\text { jujur tentang jenis-jenis usaha } \\
\text { dan kegiatan ekonomi melalui } \\
\text { pemanfaatan bahasa Indonesia } \\
\text { 2.4 Memiliki kepedulian } \\
\text { terhadap lingkungan dan sumber } \\
\text { daya alam melalui pemanfaatan } \\
\text { bahasa Indonesia } \\
2.5 \text { Memiliki perilaku jujur dan }\end{array}$ \\
\hline
\end{tabular}




\begin{tabular}{|c|c|}
\hline & $\begin{array}{l}\text { santun terhadap nilai } \\
\text { peninggalan sejarah dan } \\
\text { perkembangan Hindu-Budha di } \\
\text { Indonesia melalui pemanfaatan } \\
\text { bahasa Indonesia }\end{array}$ \\
\hline $\begin{array}{l}\text { 3. Memahami pengetahuan faktual } \\
\text { dengan cara mengamati dan menanya } \\
\text { berdasarkan rasa ingin tahu tentang } \\
\text { dirinya, makhluk ciptaan Tuhan dan } \\
\text { kegiatannya, dan benda-benda yang } \\
\text { dijumpainya di rumah, di sekolah dan } \\
\text { tempat bermain }\end{array}$ & $\begin{array}{l}\text { 3.1 Menggali informasi dari teks } \\
\text { laporan hasil pengamatan tentang } \\
\text { gaya, gerak, energi panas, bunyi, } \\
\text { dan cahaya dengan bantuan guru } \\
\text { dan teman dalam bahasa } \\
\text { Indonesia lisan dan tulis dengan } \\
\text { memilih dan memilah kosakata } \\
\text { baku } \\
\text { 3.2 Menguraikan teks instruksi } \\
\text { tentang pemeliharaan } \\
\text { pancaindera serta penggunaan } \\
\text { alat teknologi modern dan } \\
\text { tradisional dengan bantuan guru } \\
\text { dan teman dalam bahasa } \\
\text { Indonesia lisan dan tulis dengan } \\
\text { memilih dan memilah kosakata } \\
\text { baku Mu } \\
\text { 3.3 Menggali informasi dari teks } \\
\text { wawancara tentang jenis-jenis } \\
\text { usaha dan pekerjaan serta } \\
\text { kegiatan ekonomi dan koperasi } \\
\text { dengan bantuan guru dan teman } \\
\text { dalam bahasa Indonesia lisan dan } \\
\text { tulis dengan memilih dan } \\
\text { memilah kosakata baku } \\
\text { 3.4 Menggali informasi dari teks } \\
\text { cerita petualangan tentang } \\
\text { lingkungan dan sumber daya } \\
\text { alam dengan bantuan guru dan } \\
\text { teman dalam bahasa Indonesia } \\
\text { lisan dan tulis dengan memilih } \\
\text { dan memilah kosakata baku } \\
3.5 \text { Menggali informasi dari teks } \\
\text { ulasan buku tentang nilai } \\
\text { peninggalan sejarah dan } \\
\text { perkembangan Hindu-Budha di } \\
\text { Indonesia dengan bantuan guru } \\
\text { dan teman dalam bahasa } \\
\text { Indonesia lisan dan tulis dengan }\end{array}$ \\
\hline
\end{tabular}




\begin{tabular}{|c|c|}
\hline & $\begin{array}{l}\text { memilih dan memilah kosakata } \\
\text { baku }\end{array}$ \\
\hline $\begin{array}{l}\text { 4. Memahami pengetahuan faktual } \\
\text { dengan cara mengamati dan menanya } \\
\text { berdasarkan rasa ingin tahu tentang } \\
\text { dirinya, makhluk ciptaan Tuhan dan } \\
\text { kegiatannya, dan benda-benda yang } \\
\text { dijumpainya di rumah, di sekolah dan } \\
\text { tempat berma }\end{array}$ & $\begin{array}{l}\text { 4.1 Mengamati, mengolah, dan } \\
\text { menyajikan teks laporan hasil } \\
\text { pengamatan tentang gaya, gerak, } \\
\text { energi panas, bunyi, dan cahaya } \\
\text { dalam bahasa Indonesia lisan dan } \\
\text { tulis dengan memilih dan } \\
\text { memilah kosakata baku } \\
4.2 \text { Menerangkan dan } \\
\text { mempraktikkan teks } \\
\text { arahan/petunjuk tentang } \\
\text { pemeliharaan pancaindera serta } \\
\text { penggunaan alat teknologi } \\
\text { modern dan tradisional secara } \\
\text { mandiri dalam bahasa Indonesia } \\
\text { lisan dan tulis dengan memilih } \\
\text { dan memilah kosakata baku } \\
4.3 \text { Mengolah dan menyajikan } \\
\text { teks wawancara tentang jenis- } \\
\text { jenis usaha dan pekerjaan serta } \\
\text { kegiatan ekonomi dan koperasi } \\
\text { secara mandiri dalam bahasa } \\
\text { Indonesia lisan dan tulis dengan } \\
\text { memilih dan memilah kosakata } \\
\text { baku teks cerita } \\
4.4 \text { Menyajikan teks } \\
\text { petualangan tentang lingkungan } \\
\text { dan sumber daya alam secara } \\
\text { mandiri dalam teks bahasa } \\
\text { Indonesia lisan dan tulis dengan } \\
\text { memilih dan memilah kosakata } \\
\text { baku } \\
4.5 \text { Mengolah dan menyajikan } \\
\text { teks ulasan buku tentang nilai } \\
\text { peninggalan sejarah } \\
\text { perkembangan Hindu-Budha di } \\
\text { Indonesia secara mandiri dalam } \\
\text { bahasa Indonesia lisan dan tulis } \\
\text { dengan memilih dan memilah } \\
\text { kosakata baku. }\end{array}$ \\
\hline
\end{tabular}


Kompetensi Inti (KI) dalam Kurikulum 2013, kita akan menemukan beberapa manfaat di dalamnya. Seperti dijelaskan E. Mulyasa, bahwa melalui kompetensi inti, integrasi vertikal berbagai kompetensi dasar pada kelas yang berbeda dapat dijaga. Sebagai anak tangga menuju kompetensi kelulusan multidimensi, kompetensi inti juga memiliki multidimensi. Untuk kemudahan operasionalnya, kompetensi lulusan pada ranah sikap dipecah menjadi dua. Pertama, sikap spiritual yang terkait dengan tujuan pendidikan nasional membentuk peserta didik yang beriman dan bertakwa. Kedua, sikap sosial yang terkait dengan tujuan pendidikan nasional membentuk peserta didik yang berakhlak mulia, mandiri, demokratis, dan bertanggung jawab (Andi Prastowo, 2015).

Dalam Kurikulum 2013, Kompetensi Dasar memiliki beberapa fungsi dan kegunaan, Kompetensi dasar dirumuskan untuk mencapai kompetensi inti. Pencapaian kompetensi inti yakni melalui pembelajaran kompetensi dasar yang disampaikan melalui mata pelajaran. Dimana rumusannya dikembangkan dengan memperhatikan karakteristik peserta didik, kemampuan awal, serta ciri dari suatu pelajaran. Adapun sebagai pendukung pencapaian kompetensi inti, kompetensi dasar dikelompokan menjadi empat sesuai dengan rumusan kompetensi inti yang didukungnya, yaitu : pertama, kelompok kompetensi dasar sikap spiritual (mendukung KI-1) atau kelompok 1; kedua, kelompok kompetensi dasar sikap sosial (mendukung KI-2) atau kelompok 2; ketiga, kelompok kompetensi dasar pengetahuan (mendukung KI-3) atau kelompok 3; keempat, kelompok kompetensi dasar keterampilan (mendukung KI4) atau kelompok 4. Uraian kompetensi dasar yang terperinci ini adalah untuk memastikan bahwa capaian pembelajaran tidak berhenti sampai pengetahuan saja, tetapi harus berlanjut ke keterampilan, dan bermuara pada sikap (E. Mulyasa, 2013).

Berdasarkan KI dan KD yang terdapat dalam tabel diatas dengan melihat Indikator pencapaiannya dalam buku tematik SD/MI kelas IV maka dapat disimpulkan sebagai berikut : 
a. Siswa dapat mengetahui dan memahami anugrah tuhan yang maha esa berupa bahasa indonesia yang diakui sebagai bahasa persatuan yang kokoh dan sarana belajar untuk memperoleh pengetahuan.

b. Siswa dapat mengetahui dan memahami perilaku jujur, disiplin, tanggung jawab, santun, peduli, dan percaya diri dalam berinteraksi dengan keluarga, teman, guru, dan tetangganya melalui proses interaksi bahasa indonesia dengan baik dan benar dalam kehidupan sehari-hari.

c. Siswa dapat mengetahui dan memahami hasil ciptaan tuhan, benda-benda yang dijumpainya di rumah, di sekolah dan tempat bermain melalui pengamatan serta interaksi bahasa indonesia yang baik dan benar.

d. Siswa dapat mengetahui dan memahami pengetahuan yang secara faktual dengan cara mengamati, melakukan interaksi dengan bahasa indonesia yang baik dan benar.

\section{Perkembangan Pengetahuan Siswa SD}

Seiring dengan masuknya anak kesekolah dasar, kemapuan kognitifnya urut mengalami perkembangan yang pesat. Karena dengan masuk sekolah, berarti dunia dan minat anak bertambah luas. Dengan meluasnya minat maka bertambah pula pengertian tentang manusia dan objek-objek yang sebelumnya kurang berarti bagi anak. Dalam keadaan normal, pikiran anak usia sekolah berkembang secara berangsur-angsur. Kalau pada masa sebelumnya daya fikir anak masih bersifat imajinatif dan egosentris maka pada masa ini daya pikir anak berkembang kearah berpikir kongkrit, rasional dan objektif. Daya ingatnya menjadi sangat kuat sehingga anak benar-benar berada dalam suatu stadium belajar.

Pada tahap perkembangan kognitif ialah tahap opreasi konkrit, yang berlangsung sejak anak berusia 6 tahun hingga 12 tahun. Pada waktu ini konsep yang samar-samar dan tidak jelas dari masa prasekolah menjadi lebih konkrit dan spesifik. Ini memungkinkan anak memulai berpikir secara deduktif, membentuk konsep ruang dan waktu, dan menggolong-golongkan objek. Mereka 
mampu mengambil peran orang lain dan hal ini membuka jalan ke pengertian tentang realitas yang lebih besar (Hurlock, Elizabeth B, 2006).

Anak yang berada di kelas awal SD adalah anak yang berada pada rentangan usia dini. Masa usia dini merupakan masa yang pendek, tetapi merupakan masa yang sangat penting bagi kehidupan seseorang. Oleh karena itu, pada masa ini seluruh potensi yang dimiliki anak perlu didorong sehingga akan berkembang secara optimal.

Pertumbuhan dan perkembangan merupakan dua hal yang sangat penting dan tidak dapat dipisahkan dari perjalanan hidup manusia. Pertumbuhan dan perkembangan manusia bersifat permanen, dalam arti pertumbuhan dan perkembangan berlangsung selama manusia hidup dan berakhir bersamaan dengan berakhirnya manusia (meninggal dunia). Setiap individu secara kodrat membawa variasi dan irama pertumbuhan dan perkembangan sendiri-sendiri. Hal ini menyebabkan setiap individu mempunyai perbedaanperbedaan. Teori berkaitan dengan perkembangan intelektual siswa sekolah dasar dijabarkan oleh Piaget.

Menurut teori Piaget, proses belajar dapat berlangsung jika terjadi proses pengolahan data yang aktif di pihak pembelajar. Pengolahan data yang aktif merupakan aktivitas lanjutan dari kegiatan mencari informasi dan dilanjutkan dengan kegiatan penemuan.

Piaget berpendapat bahwa "apa yang sudah ada pada diri seorang siswa (kapasitas dasar kemampuan intelektualnya atau dapat disebut dengan istilah skema) adalah dasar untuk menerima hal yang baru". Skema berfungsi mengatur interaksi siswa dengan lingkungan sekitarnya (Abdul Majid, 2014).

Piaget (1950) menyatakan bahwa setiap anak memiliki cara tersendiri dalam menginterprestasikan dan beradaptasi dengan lingkungannya (teori perkembangan kognitif). Menurutnya, setiap anak memiliki struktur kognitif yang disebut schemata yaitu sistem konsep yang ada dalam pikirin sebagai hasil pemahaman terhadap 
objek yang ada dalam lingkungannya. Pemahaman tentang objek tersebut langsung melalui proses asimilasi (menghubungkan objek dengan konsep yang sudah ada dalam pikiran) dan akomodasi (proses memanfaatkan konsep-konsep dalam pikiran untuk menafsirkan objek). Kedua proses tersebut jika berlangsung secara terus-menerus akan membuat pengetahuan lama dan pengetahuan baru menjadi seimbang. Dengan cara seperti itu secara bertahap anak dapat membangun pengetahuan melalui interaksi dengan lingkungannya. Berdasarkan hal tersebut, perilaku belajar anak sangat dipengaruhi oleh aspek-aspek dari dalam diri dan lingkungannya. Kedua hal tersebut tidak mungkin dipisahkan karena memang proses belajar terjadi dalam konteks interaksi diri anak dengan lingkungannya (Abdul Majid, 2014).

Gaya berpikir anak berkembang menjadi logis, terorganisir dan fleksibel, begitu mereka memasuki tahap concrete operational thinking. Kini mereka mampu memikirkan banyak hal pada waktu yang sama, serta dengan mudah dapat mengingat dan menarik memori dengan lebih lancar.

Sejak usia 8 hingga 9 tahun, anak-anak :

a. Memiliki kemampuan mengingat dan konsentrasi yang mengingat. Begitu pula dengan kemampuan berbicara dan mengekspresikan ide/pendapatnya.

b. Belajar untuk merencanakan sesuatu kedepan serta mengevaluasi setiap tindakannya.

c. Kemampuan berpikir dan menalarnya meningkat.

d. Dapat mengatasi ide-ide yang abstrak.

e. Menikmati tipe aktivitas yang berbeda-beda, seperti bergabung dalam club tertentu, bermain game, serta mengoleksi bendabenda tertentu.

f. Menikmati melakukan proyek-proyek, seperti menjahit atau membuat bermacam-macam benda dari kayu (woodwork).

Sejak usia 10 hingga 11 tahun, anak-anak : 
a. Mengembangkan nalar spasial, yaitu kemampuan memahami serta menarik kesimpulan, dengan menggunakan tanda-tanda yang menyampaikan informasi jarak atau arah.

b. Mulai memahami motif di balik tindakan seseorang

c. Dapat berkonsentrasi lebih lama dalam mengajarkan sesuatu,

d. Mulai merancang strategi memori

e. Akan mengembangkan bakat-bakat tertentu. Menunjukan keterampilan tertentu dalam menulis, matematika, musik, atau seni (Corolyn Meggitt, 2013).

Berbicara kaitan dengan perkembangan pengetahuan siswa SD/MI, hal ini juga tidak terlepas dari proses pembelajaran berdasarkan Kurikulum 2013 yakni pembelajaran tematik yang dimana memiliki ciri khas dan karakteristik tersendiri :

a. Pengalaman dan kegiatan belajar sangat relevan dengan tingkat perkembangan dan kebutuhan siswa sekolah dasar;

b. Kegiatan yang dipilih dalam pembelajaran tematik bertitik tolak dari minat dan kebutuhan siswa;

c. Kegiatan belajar akan lebih bermakna dan berkesan bagi peserta didik sehingga hasil belajar dapat bertahan lebih lama;

d. Membantu mengembangkan keterampilan berpikir siswa;

e. Menyajikan kegiatan belajar yang bersifat pragmatis sesuai dengan permasalahan yang sering ditemui peserta didik di lingkungannya; dan

f. Mengembangkan keterampilan sosial siswa, misalnya: kerjasama, toleransi, komunikasi, dan tanggap terhadap gagasan orang lain.

Sebelum metode tematik ini ngetren, pembelajaran di SD/MI juga menggunakan metode pembelajaran dengan pola jam pelajaran. Nah sekarang perbandingan keduanya, yaitu tematik dan pola jam pelajaran bagi tingkat SD. Begini, Dengan memperhatikan kedua alasan diberlakukannya pembelajaran tematik jelaslah bahwa pembelajaran tematik lebih baik dari pada pelajaran dengan pola mata pelajaran. Selain itu ada beberapa keuntungan lain dilaksanakan pembelajaran tematik, antara lain: 
a. Pembelajaran menjadi menyenangkan.

Siswa sungguh senang karena pembelajaran dikelola sesuai dengan perkembangan jiwa anak. Dengan pembelajaran tematik, khususnya dengan buku Grasindo, setiap hari siswa diajak bernyanyi, bermain dan mendengarkan cerita. Dunia anak adalah bermain, menyanyi dan mendengarkan ceritera. Guru dapat leluasa mengatur waktu untuk ketiga kegiatan tersebut, sebab kegiatan belajar tidak dikotak-kotak lagi dengan mata pelajaran. Guru dan siswa tidak perlu bertanya, "Sekarang mata pelajaran apa?" Siswa sungguh senang, karena belajar dengan bermain dan melakukan kegiatan kreatif

b. Siswa mudah memusatkan perhatian

Dalam pembelajaran tematik kegiatan berjalan mengalir tanpa dipenggal-penggal dengan pergantian jam pelajaran. Perhatian siswa tidak terpecah-pecah. Lainnya halnya dengan pembelajaran yang disusun berdasarkan jam pelajaran. Setiap ganti jam pelajaran siswa harus kembali dari awal. Mengingat kembali materi terakhir pada hari sebelumnya. Seringkali ada kegiatan yang belum tuntas terpaksa harus diakhiri karena ada pergantian jam pelajaran. Lebih bermasalah lagi kalau gurunya juga harus ganti.

Penguasaan kompetensi akan lebih kuat dan mendalam. Dengan perhatian yang lebih terpusat dan kegiatan yang lebih tuntas, ditambah lagi dengan suasana yang menyenangkan serta materi sesuai dengan konteksnya, maka dapat diharapkan penguasaan kompetensi siswa lebih kuat dan mendalam.

c. Hemat waktu

Dalam pembelajaran dengan mata pelajaran sering ditemukan tumpang tindih. Misalnya Pelajaran Bahasa Indonesia memerlukan wacana sebagai sumber belajar. Dalam wacana tersebut memuat materi pelajaran lain. Selain itu ketika siswa menyusun atau membuat kalimat, mendeskripsikan suatu benda, dan menceritakan pengalaman sering terkait dengan materi pelajaran lain. Sebaliknya semua matapelajaran di luar Bahasa 
Indonesia pun anak harus menyusun kalimat, mendeskripsikan suatu benda dan sebagainya, yang sebetulnya hal itu terkait dengan pelajaran bahasa Indonesia. Dengan pembelajaran tematik tidak perlu dibedakan antara kalimat pelajaran Bahasa Indonesia atau kalimat pelajaran lainnya. Dengan demikian jelaslah bahwa pembelajaran tematik sungguh-sungguh menghemat waktu.

Selain kelebihan di atas pembelajaran tematik memiliki beberapa kelemahan. Kelemahan pembelajaran tematik tersebut terjadi apabila dilakukan oleh guru tunggal. Misalnya seorang guru kelas kurang menguasai secara mendalam penjabaran tema sehingga dalam pembelajaran tematik akan merasa sulit untuk mengaitkan tema dengan mateti pokok setiap mata pelajaran. Di samping itu, jika skenario pembelajaran tidak menggunakan metode yang inovatif maka pencapaian Standar Kompetensi dan Kompetensi Dasar tidak akan tercapai karena akan menjadi sebuah narasi yang kering tanpa makna (Abdul Majid, 2014).

\section{Implikasi Materi Bahasa Indonesia Dalam Buku Tematik Kelas} IV

Guru pada tingkat SD/MI harus memilik ilmu dan kecakapan-kecakapan keguruan. Agar mampu menyampaikan ilmu pengetahuan atau bidang studi yang diajarkannya secara mendalam dan luas. Untuk dapat menyajikan dan menyampaikan materi pengetahuan atau bidang studi dengan tepat, guru juga dituntut menguasai strategi serta metode mengajar dengan baik. Ia diharapkan dapat mempersiapkan pembelajaranm, melaksanakan dan menilai hasil belajar para siswa dengan baik, dapat memilih dan menggunakan model-model interaksi belajar mengajar yang tepat, mengelola kelas dan membimbing perkembangan siswa dengan tepat pula (Sukmadinata, 2003:256).

Siswa yang telah mampu belajar lebih mandiri akan lebih kritis dalam menanggapi segala sesuatu di sekelilingnya. Sikap kritis tersevut terutama ditujukan terhadap gurunya sendiri. Siswa akan lebih kritis menilai integrasi guru. Mereka akan menilai gurunya 
secara keseluruhan, dari mulai cara berpakaian, tingkah laku, bahasa, wawasan, pengetahuan, dan sebagainya. Seorang guru yang menjadi suri tauladan yang baik akan memiliki wibawa dihadapan siswa. Dan hanya guru yang memiliki yang akan mampu menciptakan kondisi kelas yang kondusif.

Adapun dampak yang dirasakana siswa sebagai subjek dalam kegiatan pembelajaran terhadap perkembangan pengetahuan materi bahasa indonesia dalam buku tematik SD/MI sangat signifikan. Hal ini mengharus siswa untuk mengkondisikan dirinya dengan baik, sehingga siswa dituntut untuk melakukan hal-hal sebagai berikut :

a. Siswa harus siap mengikuti kegiatan pembelajaran yang dalam pelaksanaannya dimungkinkan untuk bekerja baik secara individual, pasangan, kelompok kecil ataupun klasikal.

b. Siswa harus siap mengikuti kegiatan pembelajaran yang bervariasi secara aktif misalnya melakukan diskusi kelompok, mengadakan penelitian sederhana, dan pemecahana masalah (Abdul Majid, 2014).

Berdasarkan hasil observasi dan wawancara yang dilakukan di SDN Kedungpring bahwa proses pembelajaran berdasarkan Kurikulum 2013 dengan pembelajaran tematik sangat bagus dan menarik karena siswa dituntut lebih aktif dan kreatif, meskipun dalam penerapannya masih terdapat kesulitan dan hambatan yang cukup bearti yakni yang bekaitan dengan materi yang memadukan berbagai disiplin ilmu sehingga memerlukan manajemen pembelajaran yang cukup kompleks, waktu pembelajaran yang dianggap cukup singkat, serta sarana dan prasarana yang belum memadai.

Dalam buku tematik SD/MI pada mata pelajaran bahasa indonesia tidak diajarkan secara terperinci, sistimatis atau lebih jelas seperti yang diajakarkan dalam buku Kurikulm Tingkat Satuan Pendidikan (KTSP). Misalnya materi bahasa indonesia tingkat $\mathrm{SD} / \mathrm{MI}$ tentang penulisan huruf besar dan huruf kecil, kalimat baku 
dan kalimat tidak baku, menulis ide pokok dalam paragraf, tanda petik, cara membaca simbol atau lambang.

Untuk menambah wawasan peserta didik yang berkaitan dengan materi-materi bahasa indonesia yang disebut diatas maka pihak sekolah dan pendidik (guru) berupaya untuk mencarikan sebuah solusi yakni dengan mengadakan pembelajaran tambahaan atau les. Hal ini dilakukan diluar waktu proses pembelajaran berlangsung. Selain itu pendidik (guru) juga mengambil sumbersumber lain tentang materi bahasa indonesia diluar buku tematik, misalnya yang terdapat dalam buku Kurikulum Tingkat Satuan Pendidikan (KTSP) (Sugeng Rianto, 2016).

\section{SIMPULAN}

Berdasarkan uraian materi diatas, maka dapat diambil beberapa kesimpulan sebagai berikut : (1) Adapun muatan materi bahasa indonesia dalam buku tematik SD/MI kelas empat yang terdiri dari 9 (sembilan) tema yakni (a) Indahnya kebersamaan; (b) Selalu berhemat energi; (c) Peduli terhadap makhluk hidup; (d) Berbagai pekerjaan; (e) Menghargai jasa pahlawan; (f) Indahnya negeriku; (f) Cita-cita ku; (g) Daerah tempat tinggal ku; (h) Makanan sehat dan bergizi. Yang dimana materi bahasa Indonesia tidak muncul secara eksplisit namun terintegrasi pada mata pelajaran lain. Kemudian untuk mengetahui pencapaian materi dalam proses pembelajaran, guru harus melihat serta memperhatikan Kompetensi Inti, Kompetensi Dasar serta indikatornya; (2) Siswa pada tingkat SD/MI, pada aspek kognitif atau pengetahuannya mengalami perkembangan yang cuku pesat. Hal ini dapat dilihat bahwa daya pikir anak berkembang kearah berpikir kongkrit, rasional dan objektif. Hal ini tentunya sangat relevan dengan proses pembelajaran menggunakan buku tematik yang notabenya siswa dituntut agar lebih aktif dan kreatif serta mengaktualiasikan pengetahuan yang didapatnya dengan keadaan yang ada di sekitarnya; (3) Dalam materi bahasa indonesia dalam buku tematik SD/MI tidak dibahas secara lugas dan jelas seperti dalam buku Kurikulum Tingkat Satuan Pendidikan (KTSP) maka pihak sekolah dan guru (pendidik) mengadakan proses 
pembelajaran tambahan atau les. Sehingga berdampak pada pengetahuan siswa yakni siswa tidak memiliki pengetahuan tentang penulisan huruf besar dan huruf kecil, kalimat baku dan kalimat tidak baku, menulis ide pokok dalam paragraf, tanda petik, cara membaca simbol atau lambang.

\section{DAFTAR PUSTAKA}

Abdul Majid. 2014. Pembelajaran Tematik Terpadu, Bandung, Rosda Karya.

Andi Prastowo. 2015. Menyusun Rencana Pelaksanaan Pembelajaran (RPP) Tematik Terpadu, Implementasi Kurikulum 2013 untuk SD/MI, Jakarta, Prenadamedia.

Corolyn Meggitt. 2013. Memahami Perkembangan Anak, Jakarta, Tim Indeks.

E. Mulyasa. 2013. Pengembangan dan Implementasi Kurikulum 2013, Bandung, Remaja Rosdakarya.

Hurlock, Elizabeth B. 2006. Perkembangan Anak, Jakarta, Erlangga.

Kementrian Pendidikan dan Kebudayaan. 2014. Buku Tematik Kelas 4, Jakarta, Kementrian Pendidikan dan Kebudayaan.

Kementrian Pendidikan dan Kebudayaan. 2013. Kompetensi Dasar Sekolah Dasar (SD)/Madrasah Ibtidaiyah (MI), Jakarta, Kementrian Pendidikan dan Kebudayaan.

Nana Syaodih. 2009. Metode Penelitian Pendidikan, Bandung, PT Remaja Rosdakarya.

Ridwan Abdullah Sani. 2014. Inovasi Pembelajaran, Bandung, Rosda Karya. 